\title{
Amplicon Sequencing Reveals Extensive Coinfections of Foliar Pathogens in Soybean
}

\author{
Gustavo A. Díaz-Cruz ${ }^{1,2}$ and Bryan J. Cassone ${ }^{2, \dagger}$ \\ ${ }^{1}$ Department of Biology, Memorial University of Newfoundland, St. John's, NL A1C 5S7, Canada \\ ${ }^{2}$ Department of Biology, Brandon University, Brandon, MB R7A 6A9, Canada
}

\begin{abstract}
Soybean (Glycine max) is one of the most economically important crops grown in North America and in other regions worldwide. However, the plant is susceptible to a variety of foliar pathogenic microorganisms, some of which are a significant threat to production. Several molecular and serological approaches are currently available to diagnose plant pathogens, but all have limitations including their capability to accurately detect coinfections of individual plants. We therefore used $16 \mathrm{~S}$ and internal transcribed spacer amplicon sequencing to identify the suite of bacterial

alternata, and Pseudomonas spp. Importantly, we found that most of plants were infected by more than one putative pathogen, with $64 \%$ of V $2 / 3$ and $26 \%$ of R6 plants infected by three or more pathogens. Amplicon sequencing also indicated the presence of residual pathogens that infect crops other than soybean, as well as nonfoliar pathogens and nonpathogenic microorganisms. We discuss some of the benefits and drawbacks of using amplicon sequencing to detect foliar pathogens of soybean
\end{abstract} and fungal organisms infecting 96 soybean leaf samples collected throughout southern Manitoba, Canada, at two growth stages (V2/3 and R6). We were able to confirm the presence of pathogens previously known to our sampling regions, such as Septoria glycines, Alternaria
Keywords: amplicon, bacteria, diagnostics, fungi, leaf, pathology, sequencing, soybean sequencing, pathology, soybean, diagnostics, leaf, bacteria, fungi
Soybean (Glycine max L.) is one of the most economically important crops in North America. In Canada, it has been grown for $>70$ years and has recently seen dramatic increases in acreage planted. Indeed, there are currently 5.7 million acres dedicated to this crop, with $>6$ million metric tons in production (Statistics Canada 2018). As with all crops, soybean is host to a diverse collection of microorganisms, some of which cause diseases that threaten yields throughout Canada and other soybean growing regions (Ortíz-Castro et al. 2009; Turner et al. 2013). These pathogens may infect the foliar, stem, and root tissues of the plant and include bacteria, fungi, oomycetes, and viruses (Hartman et al. 2015). Foliar pathogens are particularly important, because they are estimated to cause more than half of the yield losses among the top eight soybean growing nations (Allen et al. 2017; Wrather et al. 2010). Some of the most common foliar pathogens of soybean include Pseudomonas savastanoi (bacterial blight), Septoria glycines (brown spot), Cercospora sojina (frogeye leaf spot), and Peronospora manshurica (downy mildew) (Mian et al. 2008; Williams and Nyvall 1980; Wrather et al. 2010; Wrather and Koenning 2006). Accurate, sensitive, and timely detection of these and other pathogens is integral for the management and control of soybean diseases.

Historically, foliar disease diagnoses have relied primarily on visual inspection of symptom development. Though fast, easy, and economical, this approach is prone to misidentification and relies heavily on the expertise of the surveyors. In some cases, supplemental microbiology techniques are implemented (e.g., morphology,

${ }^{\dagger}$ Corresponding author: B. J. Cassone; cassoneb@brandonu.ca

Funding: This research was supported by a Manitoba Pulse \& Soybean Growers grant awarded to B.J.C.

*The $\boldsymbol{e}$-Xtra logo stands for "electronic extra" and indicates there are supplementary materials published online.

The author(s) declare no conflict of interest.

Accepted for publication 6 July 2020 .

C 2021 The American Phytopathological Society staining, sporulation), but their application is limited to cultivable microorganisms (McCartney et al. 2003). More accurate and sensitive diagnostic approaches have since become common, namely serological (e.g., immuno-assay strips, enzyme-linked immunosorbent assay) and PCR-based (e.g., reverse transcription PCR, quantitative PCR, nested PCR) assays. However, serological testing relies on the accessibility of specific antibodies and may generate inconclusive results (Lima et al. 2012; López et al. 2003; Narayanasamy 2011). Although the PCR approaches are sensitive and, in some cases, capable of testing for multiple pathogens simultaneously (e.g., multiplex PCR), availability of the nucleotide sequence for the pathogens of interest is compulsory (Garibyan and Nidhi 2013).

Many of the challenges limiting utility of the aforementioned approaches for pathogen diagnosis are being overcome by massive parallel next-generation sequencing (NGS). A variety of sequencing platforms and sample preparation methods are routinely used, which have revolutionized our ability to detect and discover plant pathogens (Pecman et al. 2017). In addition to providing exceptional precision and resolution, they do not require specific antibodies or a priori knowledge of the DNA/RNA sequence of the inferred pathogen (Díaz-Cruz et al. 2019). To date, most studies using NGS as a diagnostic tool for plant pathogens have focused on virus discovery and include studies on pepper (Jo et al. 2017), garlic (Wylie et al. 2014), sweet potato (Kashif et al. 2012), grapevine (Coetzee et al. 2010), and tomato ( $\mathrm{Li}$ et al. 2012). In addition, some studies have used NGS for larger-scale surveys of viral diseases, particularly for field crops (Adams et al. 2013; Eichmeier et al. 2016; Hadidi et al. 2016; Han et al. 2016; Stewart et al. 2014).

In Manitoba, Canada, soybean yield losses attributed to foliar diseases are primarily the result of bacterial and fungal infections; consequently, in 2016 we used RNA sequencing for large-scale detection of other types of foliar pathogens (Díaz-Cruz et al. 2019). This study uncovered myriad bacteria and fungi that are known to cause disease in the legume and a large number of residual pathogens (i.e., microorganisms that cause disease in crops other than soybean). Although this approach had many benefits, there were also significant drawbacks. Most notably, because of the large cost associated with the library construction and sequencing, leaf samples were pooled by field and then by region. Consequently, specific information on the infection and coinfection status of individual leaves 
was not available without additional downstream diagnostic approaches (e.g., reverse transcription PCR). Given this limitation, we searched for other NGS platforms and sample preparation techniques that could provide broad-scale diagnoses of the bacteria and fungi infecting individual leaves at a reasonable cost.

In 2017, we carried out amplicon sequencing to catalog the foliar bacteria and fungi infecting soybean throughout its growing region in Manitoba, Canada. Fungi were identified via internal transcribed spacer (ITS), which possesses multiple hypervariable regions that can provide high taxonomic resolution (Schoch et al. 2012). Bacteria were detected with the $16 \mathrm{~S}$ ribosomal RNA gene, which is a region with similar characteristics to ITS in fungi (Caporaso et al. 2011). A total of 102 soybean leaves were collected from different fields during the production season (V2/3 and R6 growth stages) and assessed for the presence of microorganisms. Overall, fungal pathogens of soybean and other crops were more diverse and widespread than bacteria. In addition, we found that most symptomatic V2/3 and R6 leaves were infected by multiple pathogens. Although amplicon sequencing has clear benefits as a diagnostic tool, we also discuss some of the limitations for its application in plant disease surveys.

\section{Materials and Methods}

Field surveillance. We surveyed 38 soybean fields throughout the southern Manitoba growing region in mid-July (V2/3) and midAugust (R6) of 2017 (Fig. 1). An overview of our methods used for pathogen identification in symptomatic leaves is shown in Figure 2. In each field, leaves showing disease symptoms (e.g., chlorosis, mottling, discoloration, yellowing, spots) were collected, regardless of their position on the plant. In any given field efforts were made to sample from plants that exhibited unique foliar symptoms. In addition, we collected six symptomless samples from different fields during the late survey. Each leaf sample was photoindexed and the tissue pierced with a sterile pin and preserved in individual $15-\mathrm{ml}$ conical tubes containing RNA protection buffer. Samples were then transported to Brandon University (Brandon, Manitoba, Canada) in a cooler with ice and preserved at $-20^{\circ} \mathrm{C}$ until further processing.

DNA extraction and amplicon sequencing. A sample representative of each symptom was selected for DNA extraction. In total, 44 V2/3 samples and 52 R6 samples were subjected to genomic DNA isolation. DNA quality and quantity were determined via spectrophotometer. We then sent DNA samples to the Génome Québec Innovation Centre (McGill University, Montreal, QC, Canada) for PCR validation and reaction, amplicon barcoding, and normalization. The 16S primer sequences used were 515F: GTGCCAGCMGCCGCGG TAA and 806R: GGACTACHVGGGTWTCTAAT (Caporaso et al. 2011), and the ITS primers were ITS1F: CTTGGTCATTTAGAG GAAGTAA and ITS2: GCTGCGTTCTTCATCGATGC (Gardes and Bruns 1993; White et al. 1990). We inspected the resultant amplicon libraries for quality via capillary electrophoresis, and they were sequenced in paired-end 300-bp fashion. The raw sequence reads can be retrieved from the National Center for Biotechnology Information Sequence Read Archive under the accession number PRJNA551880.

Data processing and analysis. We analyzed the amplicon sequencing data. Raw reads were imported and trimmed for quality and adapter sequences with the default quality limit $=0.05$ and ambiguous limit $=2$. Reference-based Operational Taxonomic Unit (OTU) picking was carried at a 97\% sequence similarity threshold with the UNITE+INSDC database (UNITE Community 2017) for fungal communities and SILVA 16S release 128 (Quast et al. 2013) for bacterial communities. In both cases, the creation of new OTUs was permitted for clusters not found in the database. We then

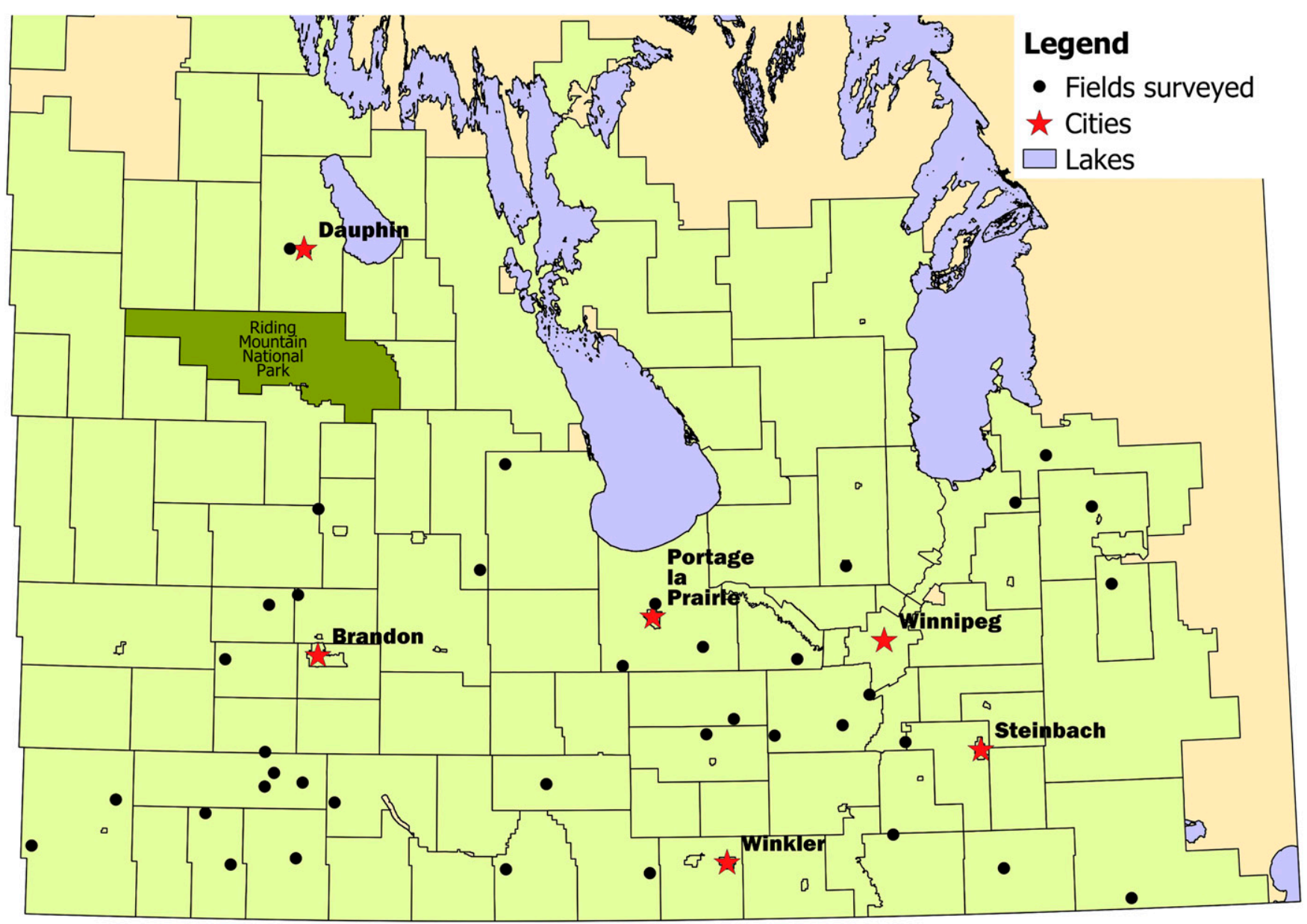

Fig. 1. Soybean field sites surveyed in southern Manitoba in 2017. Symptomatic soybean leaves were collected in mid-July (V2/3) and mid-August (R6). 
filtered the resultant OTU abundance tables to remove sequences that were not of microbial origin (e.g., chloroplast, mitochondria) or could not be resolved taxonomically. The OTU data were subsequently sorted at the species and genus levels for both bacterial and fungal sequences. For each sample, microorganisms were removed if they were present in $<0.5 \%$ of the total reads (unless otherwise stated). The incidence and relative abundance of each microorganism were then determined at each growth stage. Incidence was defined as the proportion of samples that were positive for a given pathogen, whereas relative abundance represented the percentage of reads in a positive sample that were derived from a given microorganism in comparison with the total number of reads (filtered).

\section{Results}

To characterize the bacterial and fungal pathogens infecting symptomatic soybean leaves collected from fields in Manitoba, Canada, we performed $16 \mathrm{~S}$ and ITS amplicon sequencing, respectively. Supplementary File $\mathrm{S} 1$ shows the number of reads that clustered into OTUs for each bacterial and fungal sample. Sequencing of the $16 \mathrm{~S}$ region generated $8,323,147$ paired-end reads $(27,874$ to 106,794 per sample), and ITS sequencing yielded $8,462,942$ (40,172 to 105,724 per sample). The proportion of these reads that clustered into OTUs was higher for fungal samples (52\%) than for bacteria (42\%). Furthermore, we identified more fungal diversity, with 2,072 fungal OTUs representing 4 phyla, 19 classes, 63 orders, 155 families, and 295 genera. The $16 \mathrm{~S}$ reads matching to nonmicrobial sequences (i.e., chloroplasts and mitochondria) comprised between 30 and $65 \%$ of the filtered reads in OTUs per sample. After removal of nonmicrobial contamination, 57 bacterial OTUs were grouped into 6 phyla, 9 classes, 13 orders, 17 families, and 25 genera. For subsequent analyses, the genera and species-level (where possible) data were sorted into three categories: pathogens, residual pathogens, and nonpathogens. The first group corresponded to known diseasecausing microorganisms of soybean, whereas the second groups referred to pathogens of other crops that are not known to infect soybean. Nonpathogens are microorganisms with no known pathogenicity effects on crops.

Pathogenic fungi were widespread and diverse, whereas pathogenic bacteria were limited. Table 1 shows the pathogenic fungi and bacteria present at the V2/3 and R6 growth stages with their respective incidence and relative abundance in positive samples. The bacterial analysis revealed a small number of potential pathogens, all of which belonged to the Pseudomonas genera. Interestingly,
Pseudomonas syringae, a species that includes the well-known pathovar glycinea, was not detected in our foliar samples, possibly because of poor resolution of amplicons for this genus at the species level. The predominant Pseudomonas was an uncultured bacterium, which was detected in $11 \%$ and $19 \%$ of early and late stage samples, respectively. When present in a leaf sample it was highly abundant, accounting for most sequences $(>90 \%)$ of bacterial origin. On the other hand, putative fungal pathogenic microorganisms were widespread and more diverse. The predominant species was the causal agent of brown spot, $S$. glycines. In the early stage, this fungus was found in more than two thirds of the leaves, whereas the late stage showed an incidence of $44 \%$. S. glycines was found in particularly high abundance at the V2/3 stage, accounting for half of the sequencing reads in positive samples on average. Though found in low abundance in infected samples, Alternaria alternata was present in $20 \%$ of V2/3 and half of R6 leaf samples. Another putative soybean pathogen, Plectosphaerella cucumerina, showed higher incidence and abundance in V2/3 soybean, whereas Epicoccum nigrum was present in higher frequencies in R6 plants with similar abundance between growth stages. Several genera were also identified that include known pathogenic fungi (e.g., Cercospora, Phoma, Stemphylium, Xylariales, Fusarium), but these OTUs could not be resolved to the species level. In our control samples, six putative fungal pathogens were identified: A. alternata, Alternaria spp., E. nigrum, Fusarium spp., $P$. cucumerina, and Stemphylium spp. However, these microorganisms were found at low levels ( $<5 \%$ of sequencing reads per sample on average) in comparison with the symptomatic tissues.

Most soybean leaves were infected by more than one pathogen. Although we identified myriad pathogenic bacteria and fungi infecting soybean leaves, we next wanted to determine whether coinfection of multiple pathogens is common in our survey area. Table 2 shows the proportion of leaf samples with more than one putative diseasecausing microorganism present. Nearly all symptomatic V2/3 leaves $(93 \%)$ were infected with at least two pathogens at the early stage, with two thirds showing the presence of at least three pathogens. The number of coinfections was generally lower for the R6 stage, with $71 \%$ and $27 \%$ of leaves infected with two or three pathogens, respectively. Approximately $23 \%$ of V2/3 and $6 \%$ of R6 samples were infected with five or more pathogens. When we used higher $(1 \%)$ and lower $(0.1 \%)$ stringency cutoff thresholds to detect the presence of pathogens, the incidence of coinfections changed. There also appeared to be a nonrandom association of different pathogens

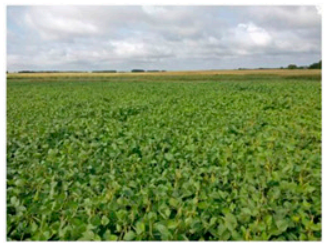

1) Visit to soybean field

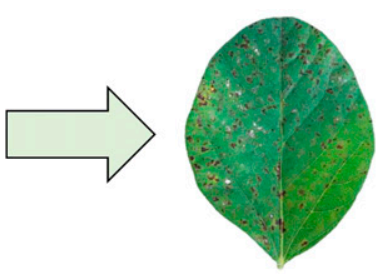

2) Collection of symptomatic leaves
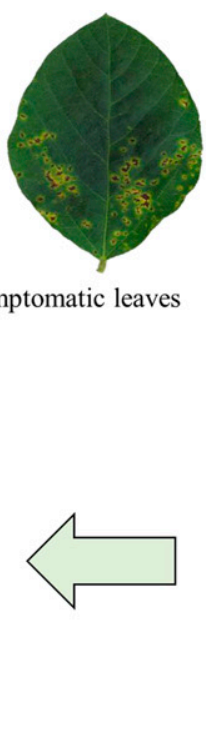

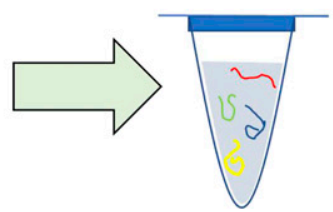

3) Isolation of gDNA

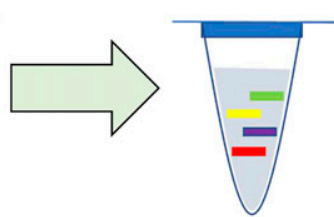

4) Preparation of amplicon library

\section{acggtgagcagagag \\ gtagcgtagcgatgetatta \\ cgtgetgagcaaatattc \\ atatctattgatggatat}

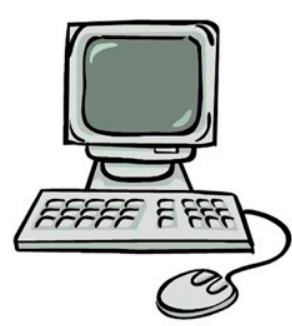

6) Pathogen identification through computational biology
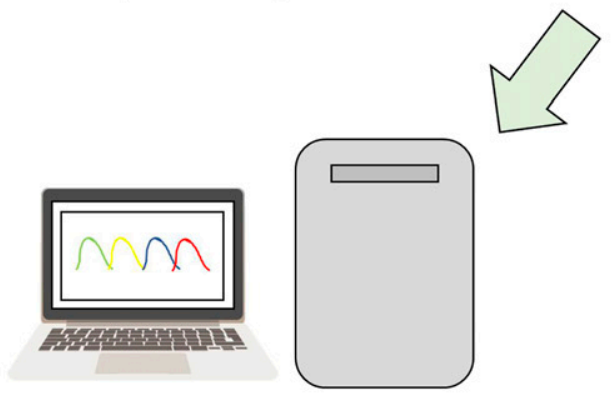

5) Illumina sequencing $16 \mathrm{~S}$ and ITS regions

Fig. 2. Workflow used to diagnose bacterial and fungal pathogens from symptomatic soybean leaves through amplicon sequencing. 
in these coinfections. For instance, symptomatic leaves showing a primary $S$. glycines infection tended to also be infected (at lower levels) with Alternaria spp., Cercospora spp., or Stemphylium spp. To aid future surveys that rely on visual assessment of foliar disease symptoms for pathogen diagnoses, we have presented the amplicon analysis for each early- and late-stage sample with a photographic record (Supplementary Files S2 and S3). The taxonomy and number of reads from each microorganism meeting our $0.5 \%$ cutoff threshold are also displayed.

Soybean leaves showed high incidence of fungal residual pathogens. Many plant pathogens overwinter in the soil or on plant refuse and can subsequently reinfect the crop in the next growing season. Growing a series of different types of crops (i.e., crop rotation) is a broadly implemented strategy to combat reinfection, because most foliar pathogens have only one or a few host plants and thus cannot successfully colonize the tissues of the newly planted crop. We therefore searched our OTU dataset for the presence of these residual pathogens, which are known infect crops in Manitoba other than soybean (Supplementary File S4). Our OTU data uncovered a total of $26 \mathrm{pu}-$ tative residual pathogen species and genera, of which all but one (Pantoea) was fungal. Interestingly, many of the residual pathogens were detected only at the V2/3 stage (e.g., Cladosporium herbarum, Parastagonospora avenae, Pyrenophora bromi), and those found at both growth stages were typically more common and abundant earlier in the growing season. Overall, Alternaria infectoria and Cladosporium perangustum were the two most prevalent species in our sampling region, both of which belong to genera known to have strong saprophytic capabilities (Bensch et al. 2012; Thomma 2003). Because the leaf samples were infected by soybean pathogens, it is likely that they took advantage of debilitated tissue as a nutrient source.
Nonpathogenic microorganisms are predominantly yeasts. Although pathogenic bacteria and fungi can detrimentally affect their host plants, some leaf-microorganism interactions can improve plant performance and health. We were therefore interested in characterizing the microbial communities inhabiting soybean leaves that are not known to be pathogenic (Supplementary File S5). Nonpathogenic bacteria accounted for six different species with low incidence, mostly present in the late stage. Similar to residual pathogens, fungi were more diverse than bacteria, and more species and genera were identified at the V2/3 stage than the R6 stage. The most commonly identified nonpathogens were from the genera Bulleromyces and Vishniacozyma, both of which showed greater incidence and abundance at the late stage. Indeed, Vishniacozyma was present in all of our R6 foliar tissue samples, with more than $26 \%$ of sequencing reads attributed to this yeast on average.

\section{Discussion}

Leaf-microorganism interactions can have a major influence on plant health and performance. Similar to other economically important crops, soybean plays host to a variety of bacteria and fungi, some of which can cause disease and detrimentally affect growth and development. We previously implemented high-throughput sequencing approaches to detect pathogens of soybean throughout southern Manitoba, Canada (Díaz-Cruz et al. 2019). Although we identified myriad pathogens, including some not previously known to occur in our sampling region, large-scale data collection on the infection and coinfection status of individual leaves was not cost-effective and thus required supplementary targeted PCR-based approaches. We therefore implemented a more cost-effective approach, $16 \mathrm{~S}$ and ITS amplicon sequencing, to identify the bacterial and fungal organisms associated with symptomatic leaves obtained from different

Table 1. Foliar pathogens of soybean identified in southern Manitoba in 2017 by amplicon sequencing. The percentage of samples positive for a given pathogen is displayed for both growth stages sampled. For positive samples, the representative pathogen was present in $\geq 0.5 \%$ of the total sequencing reads.

\begin{tabular}{|c|c|c|c|c|c|c|}
\hline \multirow[b]{2}{*}{ Genus, species } & \multicolumn{2}{|c|}{ Positive samples (\%) } & \multicolumn{2}{|c|}{ Early (V2/3) } & \multicolumn{2}{|c|}{ Late (R6) } \\
\hline & Early (V2/3) & Late (R6) & Average $^{\text {a }}(\%)$ & $\operatorname{Maximum}^{\mathbf{b}}(\%)$ & Average $^{\text {a }(\%)}$ & $\operatorname{Maximum}^{\mathbf{b}}(\%)$ \\
\hline Pseudomonas, ambiguous taxa & - & 1.92 & - & - & 18.00 & 18.00 \\
\hline Pseudomonas, uncultured bacterium & 11.36 & 19.23 & 100 & 100 & 90.73 & 100.00 \\
\hline Uncultured Pseudomonas spp. & - & 1.92 & - & - & 17.82 & 17.82 \\
\hline Alternaria alternata & 20.45 & 46.15 & 1.68 & 4.80 & 2.18 & 5.39 \\
\hline Alternaria spp. & 54.55 & 94.23 & 5.81 & 48.51 & 3.67 & 12.33 \\
\hline Cercospora spp. & 34.09 & 5.77 & 1.36 & 2.20 & 0.69 & 0.78 \\
\hline Epicoccum nigrum & 15.91 & 26.92 & 1.84 & 3.17 & 1.49 & 4.79 \\
\hline Epicoccum spp. & 9.09 & 3.85 & 1.11 & 1.35 & 6.74 & 12.61 \\
\hline Fusarium spp. & 38.64 & 13.46 & 2.21 & 7.43 & 2.53 & 6.91 \\
\hline Phoma spp. & 15.91 & 7.69 & 2.15 & 6.83 & 1.18 & 1.82 \\
\hline Plectosphaerella cucumerina & 15.91 & 1.92 & 2.98 & 7.90 & 0.58 & 0.58 \\
\hline Septoria glycines & 68.18 & 44.23 & 51.25 & 100.00 & 19.62 & 53.82 \\
\hline Stemphylium spp. & 47.73 & 40.38 & 9.76 & 60.46 & 2.65 & 15.68 \\
\hline Xylariales spp. & 13.64 & - & 4.11 & 16.95 & - & - \\
\hline
\end{tabular}

a Mean percentage of total sequencing reads attributed to a given pathogen for the positive samples.

b Positive sample with the highest proportion of total sequencing reads attributed to the given pathogen.

Table 2. Percentage of soybean leaf samples with more than one bacterial or fungal pathogen present in both the early (V2/3) and late (R6) growth stages. For pathogen detection, cutoff thresholds of $0.1,0.5$, and $1 \%$ of the total sequencing reads are shown.

\begin{tabular}{|c|c|c|c|c|c|c|c|c|}
\hline \multirow[b]{2}{*}{ Cutoff $(\%)$} & \multirow[b]{2}{*}{ Survey } & \multirow[b]{2}{*}{ No pathogens $(\%)$} & \multirow[b]{2}{*}{1 Bacterium $^{\text {a }}(\%)$} & \multirow[b]{2}{*}{1 Fungus $^{\mathbf{b}}(\%)$} & \multicolumn{4}{|c|}{ Number of pathogens $(\%)$} \\
\hline & & & & & $\geq 2$ & $\geq 3$ & $\geq 4$ & $\geq 5$ \\
\hline \multirow[t]{2}{*}{0.1} & Early (V2/3) & 2.27 & 15.91 & 0.00 & 97.73 & 95.45 & 79.55 & 68.18 \\
\hline & Late (R6) & 0.00 & 21.15 & 0.00 & 100.00 & 92.31 & 82.69 & 63.46 \\
\hline \multirow[t]{2}{*}{0.5} & Early (V2/3) & 4.55 & 11.36 & 2.27 & 93.18 & 63.64 & 40.91 & 22.73 \\
\hline & Late (R6) & 3.85 & 19.23 & 25.00 & 71.15 & 26.92 & 9.62 & 5.77 \\
\hline \multirow[t]{2}{*}{1} & Early (V2/3) & 6.82 & 11.36 & 36.36 & 56.82 & 29.55 & 20.45 & 6.82 \\
\hline & Late (R6) & 13.46 & 13.46 & 42.31 & 42.31 & 13.46 & 5.77 & 0.00 \\
\hline
\end{tabular}

\footnotetext{
${ }^{\text {a }}$ Proportion of samples with only one bacteria pathogen present. Fungal pathogens may also be present.
}

${ }^{\mathrm{b}}$ Proportion of samples with only one fungal pathogen present. Bacterial pathogens may also be present. 
soybean fields throughout our sampling region at two different growth stages. Although our primary objective was to catalog the pathogens infecting symptomatic leaves, we also generated data on the residual pathogens and nonpathogenic microorganisms. Particularly notable was our finding that most soybean leaves were infected with more than one pathogen.

Current plant disease diagnoses focus primarily on single-diseasesingle-host interactions. Indeed, foliar disease surveys typically use a variety of techniques (e.g., molecular, serological, visual inspection) to assign a specific pathogen to a symptomatic leaf. However, in nature plants interact with multiple microorganisms, including different pathogen species and genotypes. Some work has been done to identify coinfections of plant viruses (Hameed et al. 2014; Mukasa et al. 2003), but to our knowledge no study has characterized the incidence of multiple bacterial or fungal infections for economically important crops. Interestingly, we found that most soybeans were infected by more than one foliar pathogen. In fact, coinfections of more than five disease-causing microorganisms were common in our sampling region. Although misdiagnosis is often a concern for disease surveys, our results strongly suggest that underdiagnosis is also an important issue. From an application standpoint, the lack of available data describing the foliar symptoms induced by multiple pathogens makes accurate diagnoses nearly impossible. Some pathogens may also act synergistically, which can be detrimental for plants (Lamichhane and Venturi 2015). For instance, soybeans infected with both Bean pod mottle virus and Soybean mosaic virus have been shown to increase the titers of both viruses and produce significantly lower yields in comparison with singly infected plants (Calvert and Ghabrial 1983). Given the high frequency of coinfections identified in our study and the potential implications for plant disease epidemiology and management, we suggest that coinfection status should be taken into consideration in future disease surveys of soybean and other crops.

In Manitoba, foliar soybean pathogens are identified through annual Canadian Plant Disease Surveys (CPDSs), and the diagnoses are based largely on morphological and culturing techniques (Table 3). Of the eight foliar bacterial or fungal pathogens reported in CPDSs to the species or genus level, we were able to identify three of them through amplicon sequencing: $S$. glycines, A. alternata, and Pseudomonas spp. All three of these pathogens have been consistently reported in our sampling area over the past decade (Desjardins and Bisht 2011; Desjardins et al. 2012, 2013, 2014, 2015; Díaz-Cruz et al. 2019; Pradhan et al. 2016, 2017). The causal agent of brown spot, $S$. glycines, was frequently found at both the V2/3 and R6 growth stages, with symptomatic plants typically showing an abundance of this fungus. It is commonly found across soybean growing regions and reduces the yield of the crop if not properly managed (Cruz et al. 2010).The presence of this pathogen in the early stages of soybean development can be at least partially explained by splashing, which is a main driver in its dispersal (Almeida et al. 2019) and in turn can act as an inoculum source in later stages. Another pathogen ubiquitously found at both growth stages was A. alternata. Akin to $S$. glycines, this fungus is widely distributed among soybean producing regions and affects both leaves and seeds (Hartman et al. 2015). As in our study, the genus Alternaria has been routinely detected from both symptomatic and asymptomatic soybean tissue (Impullitti and Malvick 2013; Larran et al. 2002; Roy et al. 2001).
$P$. syringae pv. glycinea is the causative agent of bacterial blight, which is found in all soybean growing areas. Under cool, wet conditions losses in yield and seed quality occur, but they are low in most years (Williams and Nyvall 1980).

The remaining five foliar soybean pathogens, which were previously reported in Manitoba but not identified in our study, were Colletotrichum spp., Phyllosticta spp., Cercospora kikuchii, Xanthomonas axonopodis, and Botrytis cinerea. The latter three pathogens are considered rare in our sampling region; the annual CPDS reported each of these species once or twice between 2001 and 2015. In the case of Cercospora, microorganisms belonging to this genus were quite common, particularly in V2/3 plants, but they could not be resolved to the species level. However, we detected reads that matched C. sojina, albeit at sequencing read levels that did not meet our threshold for a positive sample. First identified in Manitoba in 2016 (Díaz-Cruz et al. 2019), this fungus is the causal agent of frogeye leaf spot. Although the disease does not cause significant economic loss in Canada, it has contributed to yield losses in the United States due to fungicide resistance (Wrather and Koenning 2006; Zhang et al. 2012). Supplementary approaches (e.g., quantitative reverse transcription PCR) are needed to determine whether the Cercospora in our positive samples is $C$. kikuchii, C. sojina, some combination of these species, or different species altogether. Two other pathogens, Phyllosticta spp. and Colletotrichum spp., are common in the province but were absent from our samples, probably because of the small number of symptomatic leaves tested.

In addition to the known pathogens in Manitoba, we identified several other putative disease-causing microorganisms through amplicon sequencing. They include the fungal organism Stemphylium spp., which was identified in nearly half of the symptomatic leaves. Although it was not possible to resolve this genus to the species level, Stemphylium botryosum is reported as the causal agent of a leaf blight (Hartman et al. 2015). It was also present in our healthy samples, which is not uncommon (Larran et al. 2002). Also notable was $E$. nigrum, which was found predominantly in the late growing stage and is known to cause leaf spot disease in legumes (Hartman et al. 2015; Mahadevakumar et al. 2014). We also uncovered a variety of nonfoliar species or genera containing pathogenic microorganisms known to infect the roots or stems of soybean, such as $P$. cucumerina (Abad et al. 2000; Hartman et al. 2015), Fusarium spp. (Wrather et al. 2010; Zhang et al. 2010), and Phoma spp. (Kövics et al. 2014). It is unclear whether these fungi had invaded the foliar tissue or whether their presence is attributed to soil contamination or their attachment to the surface of leaves (Díaz-Cruz et al. 2019).

Although the main focus of this study was to uncover bacterial and fungal pathogens of soybean, we also identified a subset of microorganisms known to cause disease in crops other than soybean. These residual pathogens predominated early in the growing season and infected primarily brassicas and cereals. Although it is unlikely that they invaded soybean tissues, their presence in soybean fields could be caused by dispersal from nearby crop fields (Duczek et al. 1999). They could also represent relics of previous crop cycles that have reemerged after overwintering in the soil or adjacent weeds (Duczek et al. 1999; Wisler and Norris 2005). If this is the case, amplicon sequencing could have significant value as an early detection tool, allowing growers to make informed decisions on the subsequent

Table 3. Foliar bacterial and fungal pathogens of soybean previously reported in Manitoba, based on Canadian Plant Disease Surveys (2001-2015)

\begin{tabular}{lllcc}
\hline Type of pathogen & \multicolumn{1}{c}{ Disease } & \multicolumn{1}{c}{ Pathogen } & No. of reports (2001-2015) & Years reported \\
\hline Bacterial & Bacterial blight P & Pseudomonas spp. & 13 & $2001-2004,2006,2008-2015$ \\
Fungal & Bacterial pustule & Xanthomonas axonopodis pv. glycines & 1 & 2003 \\
& Cercospora blight & Cercospora kikuchii & 2 & 2009,2014 \\
& Leaf spot & Phyllosticta spp. & 5 & $2009-2012,2015$ \\
& Anthracnose & Colletotrichum spp. & 7 & $2006,2010-2015$ \\
& Gray mold & Botrytis cinerea & 1 & 2010 \\
& Brown spot & Septoria glycines & 10 & $2002-2003,2006,2008-2009,2011-2015$ \\
& Alternaria leaf spot & Alternaria alternata & 2 & $2014-2015$ \\
\hline
\end{tabular}


year's crop rotation. We also identified a large number of microorganisms that were not known pathogens of soybean or other plants. These were typically found in low incidence and predominated in $\mathrm{V} 2 / 3$ plants. It is likely that these fungi and bacteria are part of the normal microbial community of soybean leaves or act opportunistically to invade tissues that have been compromised by disease. Particularly notable were the nonpathogenic organisms belonging to Vishniacozyma, which were found in most V2/3 and all R6 samples. This genus has been isolated from leaves in different regions ( $\mathrm{Li}$ et al. 2020), associated with some leaf galls of different trees (Glushakova and Kachalkin 2017), and highly abundant on grapes (Chen et al. 2020). It is not clear whether this genus has any effects on disease progression, although it is interesting that it is also present in healthy leaves in high abundance. Another commonly found yeast, Bulleromyces spp., has been associated with different environments (Boekhout 2011). It increased in prevalence late in the growing season with, $>80 \%$ of symptomatic and healthy leaves testing positive for members of this genus.

Overall, the use of amplicon sequencing to determine causal agents of plant disease has several advantages. The most notable is its ability to detect coinfections of multiple pathogens in individual samples. Although other approaches (e.g., multiplex PCR) are capable of identifying a finite number of pathogens simultaneously, these are not typically high-throughput methods and thus are rarely incorporated into large-scale disease surveys. Identification of coinfections is desirable from a crop management standpoint, because certain microorganisms may act synergistically to significantly diminish yields relative to singly infected plants. The presence of more than one pathogen may also necessitate different strategies to combat the disease, and technical recommendations may be unsuccessful if only one pathogen is targeted. Because it is cost-effective in comparison with other NGS approaches, amplicon sequencing allows surveyors to catalog the microorganisms from hundreds of individual samples in a single run. Although our study included only 44 and 52 samples for the V2/3 and R6 stage, respectively, it could have be scaled up to a larger number of samples for more extensive analysis and for regional disease surveys that aim to elucidate the behavior and dispersal of specific diseases in different crops and conditions.

Although amplicon sequencing has several benefits, its application for pathogen diagnoses also has drawbacks. It worked well for the identification of diverse fungal taxa, but its utility was limited for bacteria because a large proportion of those sequencing reads were mitochondria or chloroplast contamination. This limitation dramatically lowered the effective number of viable sequencing reads attributed to the microbial communities inhabiting the targeted tissue and presumably masked some of the bacteria present in low abundance. Additional sequencing or enrichment may be needed to obtain the number of reads necessary for accurate detection. Furthermore, a positive sample indicates only the organisms present; supplementary testing is needed to determine whether they are actually pathogenic. Regions of the 16S and ITS genes are amplified to identify bacteria and fungi to the species level, respectively, but no such genomic features are available for viruses. Our sampling region is not known to contain economically important soybean viruses (Díaz-Cruz et al. 2019), but there are other soybean growing regions and other crops where certain viruses represent a significant threat to yields. For this reason, other methods are needed when viral pathogens are suspected (Jones et al. 2017). We encountered this situation in two samples exhibiting symptoms resembling a mosaic (E06 and L29). Subsequent RNA sequencing of these samples resulted in the positive identification of Alfalfa mosaic virus (data not published), a new soybean pathogen in our study region. Other technologies based on NGS (e.g., MinION) are also becoming available that are more tractable for field studies because of their portability and ability to generate data in real time.

There are also limitations of amplicon sequencing regarding data analysis. Although the approach is sensitive, the analysis cannot always resolve taxonomy to the species level. This is because it relies on the availability of sequences in genomics databases, such as
UNITE, NCBI, and SILVA. Indeed, uncultured or unidentified organisms and ambiguous taxa make up an important subset of the results, which reduces the overall accuracy of the analysis. Amplicon analysis also relies on a cutoff threshold for a positive diagnosis. This threshold, which represents a percentage of the total number of reads in a sample, is variable and dependent on the particular dataset (Caporaso et al. 2011; Degnan and Ochman, 2012; Goodrich et al. 2014). In our study, the number of positive samples and their coinfection status varied based on the threshold chosen. For instance, the number of $\mathrm{V} 2 / 3$ samples infected by three or more pathogens was 95,64 , and $30 \%$ when we used cutoffs of $0.1,0.5$, and $1 \%$, respectively. Additional issues are related to the expertise needed to carry out the analysis. The freely accessible software available usually requires some proficiency in computational programming. Although graphical interface-based software is commercially available to mitigate this issue, it tends to be costly. Overall, our study suggests that amplicon sequencing is a useful tool for the detection of pathogens associated with foliar diseases in soybean. It is particularly suitable for fungal diagnostics and for the identification of coinfections. With many advantages and limitations, as with any other technology, we believe this study is an important step toward the integration of molecular biology and bioinformatics for the diagnosis of plant pathogens.

\section{Acknowledgments}

We thank Kiana Wiebe, Sachi Villanueva, and Adam Klonowski for assistance with the field and molecular work. We are also grateful to Manitoba Pulse \& Soybean Growers and Manitoba Agriculture for help with the sample collections.

\section{Literature Cited}

Abad, P., Pérez, A., Marqués, M. C., Vicente, M. J., Bruton, B. D., and GarcíaJiménez, J. 2000. Assessment of vegetative compatibility of Acremonium cucurbitacearum and Plectosphaerella cucumerina isolates from diseased melon plants. EPPO Bull. 30:199-204.

Adams, I. P., Miano, D. W., Kinyua, Z. M., Wangai, A., Kimani, E., Phiri, N., Reeder, R., Harju, V., Glover, R., Hany, U., Souza-Richards, R., Deb Nath, P., Nixon, T., Fox, A., Barnes, A., Smith, J., Skelton, A., Thwaites, R., Mumford, R., and Boonham, N. 2013. Use of next-generation sequencing for the identification and characterization of Maize chlorotic mottle virus and Sugarcane mosaic virus causing maize lethal necrosis in Kenya. Plant Pathol. 62:741-749.

Allen, T. W., Bradley, C. A., Sisson, A. J., Byamukama, E., Chilvers, M. I., Coker, C. M., Collins, A. A., Damicone, J. P., Dorrance, A. E., Dufault, N. S., Esker, P. D., Faske, T. R., Giesler, L. J., Grybauskas, A. P., Hershman, D. E., Hollier, C. A., Isakeit, T., Jardine, D. J., Kelly, H. M., Kemerait, R. C., Kleczewski, N. M., Koenning, S. R., Kurle, J. E., Malvick, D. K., Markell, S. G., Mehl, H. L., Mueller, D. S., Mueller, J. D., Mulrooney, R. P., Nelson, B. D., Newman, M. A., Osborne, L., Overstreet, C., Padgett, G. B., Phipps, P. M., Price, P. P., Sikora, E. J., Smith, D. L., Spurlock, T. N., Tande, C. A., Tenuta, A. U., Wise, K. A., and Wrather, J. A. 2017. Soybean yield loss estimates due to diseases in the United States and Ontario, Canada, from 2010 to 2014.Plant Heal. Prog. 18:19-27.

Almeida, Á. M. R., Sibaldelli, R. N. R., de Oliveira Negrão Lopes, I., de Oliveira, M. C. N., and Farias, J. R. B. 2019. Horizontal and vertical droplet dispersion mimicking soybean: Septoria glycines pathosystem. Eur. J. Plant Pathol. 154 437-443.

Bensch, K., Braun, U., Groenewald, J. Z., and Crous, P. W. 2012. The genus Cladosporium. Stud. Mycol. 72:1-401.

Boekhout, T. 2011. Bulleromyces Boekhout \& Á. Fonseca (1991). Pages 1391-1394 in: The Yeasts. C. P. Kurtzman, J. W. Fell, and T. Boekhout, eds. Elsevier, Amsterdam, The Netherlands.

Calvert, L. A., and Ghabrial, S. A. 1983. Enhancement by soybean mosaic virus of bean pod mottle virus titer in doubly infected soybean. Physiol. Biochem. 73: 992-997.

Caporaso, J. G., Lauber, C. L., Walters, W. A., Berg-Lyons, D., Lozupone, C. A., Turnbaugh, P. J., Fierer, N., and Knight, R. 2011. Global patterns of 16S rRNA diversity at a depth of millions of sequences per sample. Proc. Natl. Acad. Sci. 108 (suppl 1):4516-4522.

Chen, Y., Zhang, W., Yi, H., Wang, B., Xiao, J., Zhou, X., Jiankun, X., Jiang, L., and Shi, X. 2020. Microbial community composition and its role in volatile compound formation during the spontaneous fermentation of ice wine made from Vidal grapes. Process Biochem. 92:365-377.

Coetzee, B., Freeborough, M. J., Maree, H. J., Celton, J. M., Rees, D. J. G., and Burger, J. T. 2010. Deep sequencing analysis of viruses infecting grapevines: virome of a vineyard. Virology 400:157-163.

Cruz, C. D., Mills, D., Paul, P. A., and Dorrance, A. E. 2010. Impact of brown spot caused by Septoria glycines on soybean in Ohio. Plant Dis. 94:820-826. 
Degnan, P. H., and Ochman, H. 2012. Illumina-based analysis of microbial community diversity. ISME J. 6:183-194.

Desjardins, M. L., and Bisht, V. 2011. 2010 Manitoba Crop Diagnostic Centre laboratory submissions. Pages 22-30 in: Canadian Plant Disease Survey. R. A. A. Morrall, ed. The Canadian Phytopathological Society,Winnipeg, MB, Canada.

Desjardins, M. L., Bisht, V., Deol, N., and Derksen, H. 2012. 2011 Manitoba Crop Diagnostic Centre laboratory submissions. Pages 31-39 in: Canadian Plant Disease Survey. R. A. A. Morrall, ed. The Canadian Phytopathological Society, Winnipeg, MB, Canada.

Desjardins, M. L., Bisht, V., and Derksen, H. 2013. 2012 Manitoba Crop Diagnostic Centre laboratory submissions. Pages 37-44 in: Canadian Plant Disease Survey. R. A. A. Morrall, ed. The Canadian Phytopathological Society, Winnipeg, MB, Canada.

Desjardins, M. L., Pradhan, M., and Bisht, V. 2014. 2013 Manitoba Crop Diagnostic Centre laboratory submissions. Pages 37-44 in: Canadian Plant Disease Survey. R. A. A. Morrall, ed. The Canadian Phytopathological Society, Winnipeg, MB, Canada.

Desjardins, M. L., Pradhan, M., Bisht, V., and Derksen, H. 2015. 2014 Manitoba Crop Diagnostic Centre laboratory submissions. Pages 25-32 in: Canadian Plant Disease Survey. R. A. A. Morrall, ed. The Canadian Phytopathological Society,Winnipeg, MB, Canada.

Díaz-Cruz, G. A., Smith, C. M., Wiebe, K. F., Villanueva, S. M., Klonowski, A. R., and Cassone, B. J. 2019. Applications of next-generation sequencing for large-scale pathogen diagnoses in soybean. Plant Dis. 103:1075-1083.

Duczek, L. J., Sutherland, K. A., Reed, S. L., Bailey, K. L., and Lafond, G. P. 1999. Survival of leaf spot pathogens on crop residues of wheat and barley in Saskatchewan. Can. J. Plant Pathol. 21:165-173.

Eichmeier, A., Komínková, M., Komínek, P., and Baránek, M. 2016. Comprehensive virus detection using next generation sequencing in grapevine vascular tissues of plants obtained from the wine regions of Bohemia and Moravia (Czech Republic). PLoS One 11:e0167966.

Gardes, M., and Bruns, T. D. 1993. ITS primers with enhanced specificity for basidiomycetes: application to the identification of mycorrhizae and rusts. Mol. Ecol. 2:113-118

Garibyan, L., and Nidhi, A. 2013. Polymerase chain reaction. J. Invest. Dermatol. 133:1-4.

Glushakova, A. M., and Kachalkin, A. V. 2017. Endophytic yeasts in leaf galls. Microbiology 86:250-256.

Goodrich, J. K., Di Rienzi, S. C., Poole, A. C., Koren, O., Walters, W. A., Caporaso, G., Knight, R., and Ley, R. E. 2014. Conducting a microbiome study. Cell 158:250-262.

Hadidi, A., Flores, R., Candresse, T., and Barba, M. 2016. Next-generation sequencing and genome editing in plant virology. Front. Microbiol. 7:1325.

Hameed, A., Iqbal, Z., Asad, S., and Mansoor, S. 2014. Detection of multiple potato viruses in the field suggests synergistic interactions among potato viruses in Pakistan. Plant Pathol. J. 30:407-415.

Han, J., Domier, L. L., Cassone, B. J., Dorrance, A., and Qu, F. 2016. Assessment of common soybean-infecting viruses in Ohio, USA, through multi-site sampling and high-throughput sequencing. Plant Health Prog. 17:133-140.

Hartman, G. L., Rupe, J. C., Sikora, E. J., Domier, L. L., Davis, J. A., and Steffey, K. L. 2015. Compendium of Soybean Diseases and Pests. 5th ed. APS Press, The American Phytopathological Society, St. Paul, MN.

Impullitti, A. E., and Malvick, D. K. 2013. Fungal endophyte diversity in soybean. J. Appl. Microbiol. 114:1500-1506.

Jo, Y., Choi, H., Kim, S. M., Kim, S. L., Lee, B. C., and Cho, W. K. 2017. The pepper virome: natural co-infection of diverse viruses and their quasispecies. BMC Genomics 18:453.

Jones, S., Baizan-Edge, A., MacFarlane, S., and Torrance, L. 2017. Viral diagnostics in plants using next generation sequencing: Computational analysis in practice. Front. Plant Sci. 8:1770.

Kashif, M., Pietilä, S., Artola, K., Jones, R. A. C., Tugume, A. K., Mäkinen, V., and Valkonen, J. P. T. 2012. Detection of viruses in sweetpotato from Honduras and Guatemala augmented by deep-sequencing of small-RNAs. Plant Dis. 96:1430-1437.

Kövics, G. J., Sándor, E., Rai, M. K., and Irinyi, L. 2014. Phoma-like fungi on soybeans. Crit. Rev. Microbiol. 40:49-62.

Lamichhane, J. R., and Venturi, V. 2015. Synergisms between microbial pathogens in plant disease complexes: a growing trend. Front. Plant Sci. 6:385.

Larran, S., Rollán, C., Ángeles, H. B., Alippi, H. E., and Urrutia, M. I. 2002. Endophytic fungi in healthy soybean leaves. Prod. y Protección Veg. 17: 173-178.

Li, A. H., Yuan, F. X., Groenewald, M., Bensch, K., Yurkov, A. M., Li, K., Han, P. J., Guo, L. D., Aime, M. C., Sampaio, J. P., Jindamorakot, S., Turchetti, B., Inacio, J., Fungsin, B., Wang, Q. M., and Bai, F. Y. 2020. Diversity and phylogeny of basidiomycetous yeasts from plant leaves and soil: proposal of two new orders, three new families, eight new genera and one hundred and seven new species. Stud. Mycol. 96:17-140.

Li, R., Gao, S., Hernandez, A. G., Wechter, W. P., Fei, Z., and Ling, K. S. 2012. Deep sequencing of small RNAs in tomato for virus and viroid identification and strain differentiation. PLoS One 7:1-10.
Lima, J. A. A., Nascimento, A. K. Q., Radaelli, P., and Purcifull, D. E. 2012 Serology applied to plant virology. Pages 72-94 in: Serological Diagnosis of Certain Human, Animal and Plant Diseases. M. Al-Moslih, ed. InTechOpen.

López, M. M., Bertolini, E., Olmos, A., Caruso, P., Gorris, M. T., Llop, P., Penyalver, R., and Cambra, M. 2003. Innovative tools for detection of plant pathogenic viruses and bacteria. Int. Microbiol. 6:233-243.

Mahadevakumar, S., Jayaramaiah, K. M., and Janardhana, G. R. 2014. First report of leaf spot disease caused by Epicoccum nigrum on Lablab purpureus in India Plant Dis. 98:284.

McCartney, H. A., Foster, S. J., Fraaije, B. A., and Ward, E. 2003. Molecular diagnostics for fungal plant pathogens. Pest Manag. Sci. 59:129-142.

Mian, M. A. R., Missaoui, A. M., Walker, D. R., Phillips, D. V., and Boerma, H. R. 2008. Frogeye leaf spot of soybean: a review and proposed race designations for isolates of Cercospora sojina Hara. Crop Sci. 48:14-24.

Mukasa, S. B., Rubaihayo, P. R., and Valkonen, J. P. T. 2003. Incidence of viruses and viruslike diseases of sweetpotato in Uganda. Plant Dis. 87:329-335.

Narayanasamy, P. 2011. Molecular techniques for detection of microbial pathogens. Pages 7-158 in: Molecular Biology in Plant Pathogenesis and Disease Management. Springer, Dordrecht, The Netherlands.

Ortíz-Castro, R., Contreras-Cornejo, H. A., Macías-Rodríguez, L., and LópezBucio, J. 2009. The role of microbial signals in plant growth and development. Plant Signal. Behav. 4:701-712.

Pecman, A., Kutnjak, D., Gutiérrez-Aguirre, I., Adams, I., Fox, A., Boonham, N., and Ravnikar, M. 2017. Next generation sequencing for detection and discovery of plant viruses and viroids: comparison of two approaches. Front. Microbiol. 8: 1998.

Pradhan, M., Bisht, V., and Bajracharya, P. 2016. 2015 Manitoba Crop Diagnostic Centre laboratory submissions. Pages 33-40 in: Canadian Plant Disease Survey. R. A. A. Morrall, ed. The Canadian Phytopathological Society,Winnipeg, MB, Canada.

Pradhan, M., Bisht, V., Derksen, H., and Bajracharya, P. 2017. 2016 Manitoba Agriculture Crop Diagnostic Centre laboratory submissions. Pages 33-40 in: Canadian Plant Disease Survey. J. Elmhirst, ed. The Canadian Phytopathological Society,Winnipeg, MB, Canada.

Quast, C., Pruesse, E., Yilmaz, P., Gerken, J., Schweer, T., Yarza, P., Peplies, J., and Glöckner, F. O. 2013. The SILVA ribosomal RNA gene database project: improved data processing and web-based tools. Nucleic Acids Res. 41(D1) 590-596.

Roy, K. W., Baird, R. E., and Abney, T. S. 2001. A review of soybean (Glycine max) seed, pod, and flower mycofloras in North America, with methods and a key for identification of selected fungi. Mycopathologia 150:15-27.

Schoch, C. L., Seifert, K. A., Huhndorf, S., Robert, V., Spouge, J. L., Levesque, C. A., Chen, W., Bolchacova, E., Schindel, D., et al. 2012. Nuclear ribosomal internal transcribed spacer (ITS) region as a universal DNA barcode marker for fungi. Proc. Natl. Acad. Sci. 109:6241-6246.

Statistics Canada. 2018. Table 001-0071: estimated areas, yield and production of principal field crops by Small Area Data Regions, in metric and imperial units, annual, CANSIM (database). Available at: https://www150.statcan.gc.ca/t1/ tbl1/en/tv.action?pid=3210000201 [Accessed April 20, 2018].

Stewart, L. R., Teplier, R., Todd, J. C., Jones, M. W., Cassone, B. J., Wijeratne, S., Wijeratne, A., and Redinbaugh, M. G. 2014. Viruses in maize and johnsongrass in southern Ohio. Phytopathology 104:1360-1369.

Thomma, B. P. H. J. 2003. Alternaria spp.: from general saprophyte to specific parasite. Mol. Plant Pathol. 4:225-236.

Turner, T. R., James, E. K., and Poole, P. S. 2013. The plant microbiome. Genome Biol. 14:209.

UNITE Community. 2017. Full UNITE+INSDC dataset. https://unite.ut.ee/

White, T. J., Bruns, T., Lee, S., and Taylor, J. 1990. Amplification and direct sequencing of fungal ribosomal RNA genes for phylogenetics. Pages 315-322 in: PCR-protocols: a guide to methods and applications. Academic Press, New York.

Williams, D. J., and Nyvall, R. F. 1980. Leaf infection and yield losses caused by brown spot and bacterial blight diseases of soybean. Phytopathology 70: 900-902.

Wisler, G. C., and Norris, R. F. 2005. Interactions between weeds and cultivated plants as related to management of plant pathogens. Weed Sci. 53:914-917.

Wrather, A., Shannon, G., Balardin, R., Carregal, L., Escobar, R., Gupta, G. K., Ma, Z., Morel, W., Ploper, D., and Tenuta, A. 2010. Effect of diseases on soybean yield in the top eight producing countries in 2006.Plant Health Prog. 11:2008-2013.

Wrather, J. A., and Koenning, S. R. 2006. Estimates of disease Effects on soybean yields in the United States 2003 to 2005. J. Nematol. 38:173-180.

Wylie, S. J., Li, H., Saqib, M., and Jones, M. G. K. 2014. The global trade in fresh produce and the vagility of plant viruses: a case study in garlic. PLoS One 9:e105044.

Zhang, G. R., Newman, M. A., and Bradley, C. A. 2012. First report of the soybean frogeye leaf spot fungus (Cercospora sojina) resistant to quinone outside inhibitor fungicides in North America. Plant Dis. 96:767.

Zhang, J. X., Xue, A. G., Zhang, H. J., Nagasawa, A. E., and Tambong, J. T. 2010 Response of soybean cultivars to root rot caused by Fusarium species. Can. J. Plant Sci. 90:767-776. 